University of Nebraska - Lincoln

DigitalCommons@University of Nebraska - Lincoln

USDA Forest Service / UNL Faculty Publications U.S. Department of Agriculture: Forest Service -National Agroforestry Center

2012

\title{
Quantifying Tropical Dry Forest Type and Succession: Substantial Improvement with LiDAR
}

\author{
Sebastian Martinuzzi \\ University of Idaho, martinuzzi@wisc.edu \\ William A. Gould \\ International Institute of Tropical Forestry GIS and Remote Sensing Laboratory,wgould@fs.fed.us \\ Lee A. Vierling \\ University of Idaho, leev@uidaho.edu \\ Andrew T. Hudak \\ Rocky Mountain Research Station, ahudak@fs.fed.us \\ Ross F. Nelson \\ NASA Goddard Space Flight Center, Ross.F.Nelson@nasa.gov \\ See next page for additional authors
}

Follow this and additional works at: https://digitalcommons.unl.edu/usdafsfacpub

Martinuzzi, Sebastian; Gould, William A.; Vierling, Lee A.; Hudak, Andrew T.; Nelson, Ross F.; and Evans, Jeffrey S., "Quantifying Tropical Dry Forest Type and Succession: Substantial Improvement with LiDAR" (2012). USDA Forest Service / UNL Faculty Publications. 179.

https://digitalcommons.unl.edu/usdafsfacpub/179

This Article is brought to you for free and open access by the U.S. Department of Agriculture: Forest Service -National Agroforestry Center at DigitalCommons@University of Nebraska - Lincoln. It has been accepted for inclusion in USDA Forest Service / UNL Faculty Publications by an authorized administrator of DigitalCommons@University of Nebraska - Lincoln. 


\section{Authors}

Sebastian Martinuzzi, William A. Gould, Lee A. Vierling, Andrew T. Hudak, Ross F. Nelson, and Jeffrey S. Evans 


\title{
Quantifying Tropical Dry Forest Type and Succession: Substantial Improvement with LiDAR
}

\author{
Sebastián Martinuzzi ${ }^{1,6}$, William A. Gould ${ }^{2}$, Lee A. Vierling ${ }^{1}$, Andrew T. Hudak ${ }^{3}$, Ross F. Nelson ${ }^{4}$, and Jeffrey S. Evans ${ }^{5}$ \\ ${ }^{1}$ Department of Forest Ecology and Biogeosciences, Geospatial Laboratory for Environmental Dynamics, University of Idaho, Moscow, ID, \\ 83843, U.S.A.
}

${ }^{2}$ US Forest Service International Institute of Tropical Forestry, Río Piedras, PR, 00926, U.S.A.

${ }^{3}$ US Forest Service Rocky Mountain Research Station, Moscow, ID, 83843, U.S.A.

${ }^{4}$ Biospheric Sciences Branch, NASA Goddard Space Flight Center, Code 614.4, Greenbelt, MD, 20771, U.S.A.

${ }^{5}$ The Nature Conservancy, North American Region-Science, Fort Collins, CO, 80524, U.S.A.

\section{ABSTRACT}

Improved technologies are needed to advance our knowledge of the biophysical and human factors influencing tropical dry forests, one of the world's most threatened ecosystems. We evaluated the use of light detection and ranging (LiDAR) data to address two major needs in remote sensing of tropical dry forests, i.e., classification of forest types and delineation of forest successional status. We evaluated LiDAR-derived measures of three-dimensional canopy structure and subcanopy topography using classification-tree techniques to separate different dry forest types and successional stages in the Guánica Biosphere Reserve in Puerto Rico. We compared the LiDARbased results with classifications made from commonly used remote sensing data, including Landsat satellite imagery and radar-based topographic data. The accuracy of the LiDAR-based forest type classification (including native- and exotic-dominated forest classes) was substantially higher than those from previously available data (kappa $=0.90$ and 0.63 , respectively). The best result was obtained when combining LiDAR-derived metrics of canopy structure and topography, and adding Landsat spectral data did not improve the classification. For the second objective, we observed that LiDAR-derived variables of vegetation structure were better predictors of forest successional status (i.e., mid-secondary, late-secondary, and primary forests) than was spectral information from Landsat. Importantly, the key LiDAR predictors identified within each classification-tree model agreed with previous ecological knowledge of these forests. Our study highlights the value of LiDAR remote sensing for assessing tropical dry forests, reinforcing the potential for this novel technology to advance research and management of tropical forests in general.

Abstract in Spanish is available in the online version of this article.

Key words: ALS; biodiversity; land-use legacy; secondary forests; vegetation structure.

REMOTE SENSING IS AN IMPORTANT TOOL FOR SUPPORTING RESEARCH AND MANAGEMENT OF TROPICAL DRY FORESTS (Sánchez-Azofeifa et al. 2003), one of the world's most threatened ecosystems Janzen 1988). Current limitations in remotely sensed assessments of forest types and succession, however, hamper efforts to quantify important ecosystem characteristics such as those related to biodiversity and carbon storage (e.g., Quesada et al. 2009, Sánchez-Azofeifa et al. 2009). Improved technologies are therefore needed to advance our knowledge of the biophysical and human dimensions of these ecosystems (Sánchez-Azofeifa et al. 2005, see Krishnaswamy et al. 2009). In particular, hyperspectral and LiDAR remote sensing hold a special interest because they can add a great deal of dimensionality to the spectral and structural information available to make ecological inferences (Kalacska \& Sánchez-Azofeifa 2008, Sánchez-Azofeifa et al. 2009). The process of applying these technologies in tropical dry forests is just

Received 20 June 2011; revision accepted 25 April 2012.

${ }^{6}$ Corresponding author; current address: Department of Forest and Wildlife Ecology, University of Wisconsin, Madison, WI 53706, U.S.A.; e-mail: martinuzzi@wisc.edu beginning within the scientific community. In this study, we evaluated the utility of LiDAR relative to other commonly used remote sensing data sets to: (1) classify forest types; and (2) identify successional status in a tropical dry forest of Puerto Rico.

LiDAR (i.e., light detection and ranging) uses a laser to directly measure canopy height, subcanopy topography, and the vertical distribution of intercepted surfaces, opening new opportunities for assessing forest structure and function (see Hill \& Suarez 2010). LiDAR data are becoming increasingly common and they are part of the next generation of satellite and airbornebased systems for ecological observations (e.g., Carnegie Airborne Observatory [Asner et al. 2007], National Ecological Observatory Network [NEON; Keller et al. 2008], NASA ICESat2, http:// icesat.gsfc.nasa.gov/icesat2).

As different vegetation types support different groups of organisms, maps of forest types derived from remote sensing data are commonly used to assess biodiversity and wildlife habitats (Turner et al. 2003). In this sense, the combination of Landsat satellite imagery with environmental GIS layers is one of the most common approaches for classifying vegetation (Cohen \& Goward 2004); however, accurately delineating tropical dry forest 
types has been problematic. Frequent confusion has been reported between semi-deciduous forests and shrublands/woodlands, semi-deciduous forests and evergreen forests, and scrub forest, shrublands and pastures, among others (e.g., Helmer et al. 2002, 2008, Kennaway \& Helmer 2007, Gould et al. 2008, Martinuzzi et al. 2008, see also Krishnaswamy et al. 2004, 2009 using other optical sensors). Further classification challenges may arise by the presence of forest types in different successional stages, as well as by introduced species creating novel forest types (Lugo 2009).

Recent studies in temperate zones found that LiDARderived information of canopy height can be powerful predictor of vegetation types, either alone or in combination with spectral imagery (Hill \& Thomson 2005, Antonarakis et al. 2009). In particular, LiDAR data can improve the delineation of forest classes that are spectrally similar, but structurally different (Neuenschwander et al. 2009), a problem that confounds accurate classification in tropical dry forests. In addition, because topography influences the distribution of tropical forest types at a local scale (Lugo 2005), the use of topographic information from LiDAR may prove useful for further discriminating forest types.

Understanding succession and land-use legacy is important for managing tropical forests, as they affect the structure, function, and services of these ecosystems (Chazdon et al. 2009, Quesada et al. 2009). Today, tropical dry forests occur in a dynamic mosaic of different human land uses and forest patches in different stages of development (Quesada et al. 2009). In this context, the delineation of successional stages (i.e., young, mature, and primary forests) is a topic of major research interest, but also of major technological challenges (Sánchez-Azofeifa et al. 2003, 2009, Quesada et al. 2009). Previous studies were able to separate successional stages in forests up to $30 \mathrm{yr}$ of age (i.e., in young to mid-secondary forests) using the Landsat-derived Normalized Difference Vegetation Index (NDVI; Arroyo-Mora et al. 2005, Hartter et al. 2008). In these studies, the value of the NDVI resides in its sensitivity to tree canopy cover (Feeley et al. 2005), and the fact that tree canopy cover - and the proportion of deciduous species - change within the first 20-30 yr (see Arroyo-Mora et al. 2005, Hartter et al. 2008). After that, however, the overall horizontal structure of the forest (including canopy cover) tends to stabilize (Lugo 2005), limiting the use of NDVI to further track succession. As a result, assessing succession in tropical dry forests of $>30 \mathrm{yr}$ old has been difficult (SánchezAzofeifa et al. 2003, 2009). As the vertical structure of tropical dry forests can further change after the horizontal structure stabilizes (Lugo 2005), LiDAR data may be helpful for tracking successional changes in more mature stands. This includes, for example, the identification of mature secondary forests and primary forests, which are of key value for biodiversity and conservation (Chazdon et al. 2009).

Scientists are using LiDAR to characterize forest succession. Previous work in temperate and tropical moist forests showed that LiDAR data were sensitive to successional changes (see Drake et al. 2002 and Hill \& Thomson 2005). Recently, Weber and Boss (2009) successfully separated young, intermediate, and mature stages in a broadleaf temperate forest. In a conifer forest, Falkowski et al. (2009) mapped six successional stages (from stand initiation to old growth) with an accuracy of $>95$ percent. In a tropical dry forest, Castillo-Nuñez et al. (2011) used LiDAR to delineate mechanisms of forest regeneration.

We investigated two major objectives in this study. First, we evaluated the use of airborne-based LiDAR data for classifying tropical dry forest types in an area exhibiting varied composition, including different native forest formations and a class dominated by an exotic species. Second, we explored the value of LiDAR data for identifying successional status in forests of $>30 \mathrm{yr}$ old. An overarching goal in both objectives was to compare the performance of LiDAR with similar classifications made from available Landsat imagery and non-LiDAR topographic data.

\section{METHODS}

STUdY AREA.-This study was conducted in the Guánica Biosphere Reserve in Puerto Rico (17 $58^{\prime} \mathrm{N}, 66^{\circ} 52^{\prime} \mathrm{W}$; Fig. S1). Guánica is considered to be one of the best examples of subtropical dry forests because it has been protected since the 1930s and is a local biodiversity hotspot (Gould et al. 2008). It is also a core site for the NEON program (Keller et al. 2008). The reserve comprises two main areas covering nearly 4000 ha from the shoreline of the Caribbean Sea to an elevation about $230 \mathrm{~m}$, and our study area corresponds to the largest of these portions (approx. 3000 ha; Fig. S1). Annual rainfall is $860 \mathrm{~mm}$ with a major dry period from December to March and a minor one between June and August (Medina \& Cuevas 1990). The substrate is derived from limestone with common presence of exposed rock outcrops.

Vegetation and LAND-USE HISTORY-Dry forests in the Caribbean islands are typically shorter than in other parts of the world (Murphy \& Lugo 1986). Three intergrading and edaphically determined forest types occupy most of Guánica, including: semideciduous forest (the most common type) in the internal hills and coastal areas, semi-evergreen forest in valleys and ravines with well-developed soils, and scrub forest in coastal areas and limestone outcrops. A narrow fringe of dwarf forest occurs along coastal rocky areas exposed to the ocean winds. Finally, a distinctive stand of the exotic Prosopis pallida (i.e., mesquite) occurs along an alluvial fan in the southern part of the reserve (see Table 1 for a description of the forest types). Forested wetlands (i.e., mangroves) were not considered in this study.

Guánica is a mosaic of mature forests dominated by secondary forests that have recovered after land-use abandonment occurring between the 1930s and the 1950s. The area was previously used for charcoal and fence-post production (involving logging and harvesting of stems and branches from trees), with smaller areas used for agriculture and forest plantations. Studies in the semi-deciduous forests revealed that the vegetation has recovered significantly (Murphy et al. 1995, Lugo 2005). After $45 \mathrm{yr}$ of land-use abandonment, for example, Molina Colón and Lugo (2006) found that stands previously used for charcoal pro- 
TABLE 1. Forest types in Guánica based on Lugo et al. (1978), Lugo 2005, Murpby \& Lugo (1986), Farnsworth (1993), and Gould et al. (2008). The number of field samples used by this study $(\mathrm{N})$ is included.

\begin{tabular}{|c|c|c|}
\hline Class name & $N$ & Description \\
\hline $\begin{array}{l}\text { Semi-deciduous } \\
\text { forest }\end{array}$ & 28 & $\begin{array}{l}\text { Covers about } 60 \text { percent of Guánica. Average tree } \\
\text { height is } 4.3 \mathrm{~m} \text { with tallest trees between } 7 \text { and } \\
12 \mathrm{~m} \text {. Most trees are }<10 \mathrm{~cm} \text { in diameter, with up to } \\
14,000 \text { trees per hectare and basal area about } 20 \mathrm{~m}^{2} / \\
\text { ha. Canopy cover fluctuates from } 97 \text { percent in the } \\
\text { wetter month to } 77 \text { percent in the drier month, and } \\
\text { leaf area index from } 4.3 \text { to } 2.1 \text {. }\end{array}$ \\
\hline $\begin{array}{l}\text { Semi-evergreen } \\
\text { forest }\end{array}$ & 21 & $\begin{array}{l}\text { About } 20 \text { percent of the area; in moist ravines and } \\
\text { valleys with thicker soils, abundant leaf litter, and } \\
\text { springs or runoff catchments. Trees are taller with } \\
\text { some species reaching } 10-15 \mathrm{~m} \text {, and high species } \\
\text { diversity. Includes evergreen forests. }\end{array}$ \\
\hline Scrub forest & 19 & $\begin{array}{l}\text { Covers about } 15 \text { percent of Guánica, also known as } \\
\text { shrubland/cactus. Open shrubland with cactus and } \\
\text { widely spaced stunted trees found in areas with poor } \\
\text { soil development and much exposed bedrock. }\end{array}$ \\
\hline Dwarf forest & 8 & $\begin{array}{l}\text { Along coastal rocky areas exposed to ocean winds and } \\
\text { salt spray, and composed by gnarled and twisted trees } \\
\text { with horizontal stem and canopy growing close to } \\
\text { the ground. Believed to support the oldest trees in } \\
\text { Puerto Rico. }\end{array}$ \\
\hline Mesquite forest & 7 & $\begin{array}{l}\text { Relatively homogenous stand of Prosopis pallida with a } \\
\text { dense herbaceous understory. }\end{array}$ \\
\hline
\end{tabular}

duction or agriculture recovered in $>75$ percent of the original levels of tree height, basal area, stem density, and crown area index, with slightly higher recovery values observed in those used for charcoal production. The height of mature trees may be reached after 60-70 yr (Agosto Diaz 2008). In addition, past agricultural lands are today dominated by the exotic tree Leucaena leucocephala. Despite decades of recovery, past land use still explains most of the structural and compositional variations of the semi-deciduous forests in Guánica (Agosto Diaz 2008).

REMOTE SENSING AND VEGETATION DATA.- The data for this study consisted of airborne LiDAR data, location samples for the different forest types, historic land-use information, Landsat ETM+ satellite imagery, and non-LiDAR topographic data from the Shuttle Radar Topography Mission (SRTM).

For the first objective (i.e., classifying forest types), we obtained location samples for the different forest classes based on previous studies plus additional field visits. Most samples for the semi-deciduous forest class were based on field plots established by Agosto Diaz (2008). These plots were designed using a stratified random sample technique with the objective of identifying the human and environmental factors explaining variations in forest structure, and therefore they represented an ideal training data set for our study. We visited the area during 2009 to geolocate additional vegetation plots. We used GPS surveys and visual
TABLE 2. Remote sensing-based explanatory variables.

\begin{tabular}{|c|c|}
\hline Variable name & Description \\
\hline \multicolumn{2}{|c|}{ LiDAR variables of canopy structure } \\
\hline CDENSITY1 & Canopy density 1 ; percent of returns $>0.3 \mathrm{~m}$ \\
\hline CDENSITY2 & Canopy density 2 ; percent of returns $>1.0 \mathrm{~m}$ \\
\hline CDENSITY3 & Canopy density 3 ; percent of returns $>2.0 \mathrm{~m}$ \\
\hline STRAT1 & $\begin{array}{l}\text { Stratum 1; percent of vegetation returns between } 0.3 \text { and } \\
3 \mathrm{~m}\end{array}$ \\
\hline STRAT2 & Stratum 2; percent of vegetation returns between 3 and $8 \mathrm{~m}$ \\
\hline STRAT3 & Stratum 3; percent of vegetation returns $>8 \mathrm{~m}$ \\
\hline H10th & 10th percentile of vegetation heights \\
\hline H25th & 25th percentile of vegetation heights \\
\hline HMEDIAN & Median height of vegetation returns \\
\hline H75th & 75th percentile of vegetation heights \\
\hline H90th & 90th percentile of vegetation heights \\
\hline HMEAN & Mean height of vegetation returns \\
\hline HMAX & Maximum height of vegetation returns \\
\hline HMAD & Median absolute deviation of vegetation heights \\
\hline HSD & Standard deviation of vegetation heights \\
\hline HSKEW & Skewness of vegetation heights \\
\hline HKURT & Kurtosis of vegetation heights \\
\hline HIQR & Interquartile range of vegetation heights \\
\hline \multicolumn{2}{|c|}{ Landsat ETM+ spectral variables } \\
\hline B1 & Band 1 \\
\hline B2 & Band 2 \\
\hline B3 & Band 3 \\
\hline B4 & Band 4 \\
\hline B5 & Band 5 \\
\hline B7 & Band 7 \\
\hline NDVI & Normalized difference vegetation index \\
\hline TCAP-B & Tasseled cap brightness \\
\hline TCAP-G & Tasseled cap greenness \\
\hline TCAP-W & Tasseled cap wetness \\
\hline \multicolumn{2}{|c|}{$\begin{array}{l}\text { (Note: The suffix 'wet' or 'dry' before the variable's name is added to } \\
\text { identify the image season when needed }\left[\text { e.g., NDVI } \mathrm{N}_{\mathrm{dry}}\right] \text {. Similar, the } \\
\text { symbol ' } \Delta \text { ' before the variable's name is added to denote multi-temporal } \\
\text { change [e.g., } \Delta \mathrm{NDVI}]) \text {. }\end{array}$} \\
\hline \multicolumn{2}{|c|}{ Topographic variables } \\
\hline ELEV & Elevation \\
\hline SLP & Slope \\
\hline ASP & Aspect \\
\hline CURV & Curvature \\
\hline SRAD & Area Solar Radiation \\
\hline IMI & Integrated Moisture Index (Iverson et al. 1997) \\
\hline $\begin{array}{l}\text { CTI } \\
\text { (Note: Deri }\end{array}$ & $\begin{array}{l}\text { Compound Topographic Index (Gessler et al. 1995) } \\
\text { red from both 30-m LiDAR and SRTM DEMs) }\end{array}$ \\
\hline \multicolumn{2}{|l|}{ Other } \\
\hline DIST & Distance to the coast \\
\hline
\end{tabular}

interpretation of 1-m spatial resolution color aerial photos supported by expert knowledge, for a total of 83 sample locations. All samples represented an area of at least $30 \mathrm{~m}$ by $30 \mathrm{~m}$ of the same forest type (to coincide with the geospatial grain size used 
by this study), and were separated by $>60 \mathrm{~m}$ (consistent with Agosto Diaz 2008). Finally, Agosto Diaz (2008) and E. Medina (pers. comm.) facilitated sample locations for the scrub forest and dwarf forest.

The second objective (i.e., classification of successional stages) was conducted in the semi-deciduous forest. We utilized historic land-use information for 25 plots derived from aerial photos from the 1930s, 1950s, and 1970s (Agosto Diaz 2008). We identified four different successional classes based on the year of land-use abandonment and the type of past land use. These successional classes included: (1) mid-secondary forests with a logging past (i.e., $\sim 40 \mathrm{yr}$ old stands previously logged and harvested for charcoal and fence-post production, $N=5$ ); (2) late-secondary forests with a logging past (i.e., $\sim 60 \mathrm{yr}$ old stands previously logged and harvested for charcoal and fence posts, $N=6$ ); (3) late-secondary forests with an agricultural past (i.e., $\sim 60 \mathrm{yr}$ old stands previously cleared for agriculture, $N=3$ ); and (4) primary forests (i.e., undisturbed, $\geq 90 \mathrm{yr}$ old stands, $N=11)$. Although small in sample size, the class with a history of agriculture allowed us to explore the potential separability of different historic land uses (i.e., agriculture or charcoal production) within the same successional stage (i.e., latesecondary forest).
The airborne LiDAR data were collected during January and February 2004 by 3001 Inc. and the US government, covering Puerto Rico and the U.S. Virgin Islands. The sensor recorded up to three return height values per laser pulse (i.e., first, last, and intermediate returns), and with varied pulse density. The Western half of Guánica was acquired at a density of 0.20 pulses $/ \mathrm{m}^{2}$ and the Eastern half at 0.05 pulses $/ \mathrm{m}^{2}$. These are very low data densities relative to more recent acquisitions (e.g., $>1$ pulse $/ \mathrm{m}^{2}$ ). The reported mean vertical error was $9.27 \mathrm{~cm}$.

The satellite imagery consisted of 30-m pixel Landsat ETM+ scenes from October 2002 (i.e., wet season) to January 2003 (i.e., dry season), with precision and terrain correction (i.e., Level 1T). The reported horizontal error was $2.3 \mathrm{~m}$ for the 2002 scene and $2.6 \mathrm{~m}$ for the 2003 scene.

Finally, auxiliary topographic information came from the SRTM. We used the $30-\mathrm{m}$ gridded digital elevation model (DEM). The reported mean horizontal and vertical errors are $<12$ and $10 \mathrm{~m}$, respectively, although they may vary locally (Rodríguez et al. 2006).

DATA PREPROCESSING.-We first thinned the Western portion of the data $\left(0.20\right.$ pulses $\left./ \mathrm{m}^{2}\right)$ to the same point density of the

TABLE 3. Forest type classification models $(\mathrm{N}=11$ ), including the source of predictor variables included in each model (marked with ' $X$; top section), classification accuracy (i.e., error rates for each forest type and for the entire classification, and the kappa value; in the center) and variables included in the final models (bottom). Models 1-5 were developed from single sources of predictor variables; models 6-9 from multiple sources, and models 10-11 after adding elevation (ELEV) and curvature (CURV).

\begin{tabular}{|c|c|c|c|c|c|c|c|c|c|c|c|}
\hline Model & $1^{*}$ & $2^{\dagger}$ & $3^{*}$ & $4^{\S}$ & $5^{\mathbb{9}}$ & $6^{* *}$ & $7^{\dagger \dagger}$ & $8^{+4}$ & $9^{\S \S}$ & $10^{9 \uparrow}$ & $11^{* * *}$ \\
\hline LiDAR canopy & $\mathrm{X}$ & & & & & $\mathrm{X}$ & & & $\mathrm{X}$ & $\mathrm{X}$ & \\
\hline ETM+ wet season & & $\mathrm{X}$ & & & & & $\mathrm{X}$ & $\mathrm{X}$ & $\mathrm{X}$ & & $\mathrm{X}$ \\
\hline ETM+ dry season & & & $\mathrm{X}$ & & & & $\mathrm{X}$ & $\mathrm{X}$ & $\mathrm{X}$ & & $\mathrm{X}$ \\
\hline LiDAR DEM & & & & $\mathrm{X}$ & & $\mathrm{X}$ & & & $\mathrm{X}$ & $\mathrm{X}$ & \\
\hline SRTM DEM & & & & & $\mathrm{X}$ & & & $\mathrm{X}$ & & & $\mathrm{X}$ \\
\hline ELEV and DIST & & & & & & & & & & $\mathrm{X}$ & $\mathrm{X}$ \\
\hline Scrub forest & 0.16 & 0.21 & 0.37 & 0.68 & 0.58 & 0.16 & 0.21 & 0.21 & 0.11 & 0.05 & 0.11 \\
\hline Semi-deciduous forest & 0.21 & 0.46 & 0.43 & 0.25 & 0.46 & 0.14 & 0.46 & 0.21 & 0.14 & 0.07 & 0.25 \\
\hline Dwarf forest & 0.13 & 0.38 & 0.38 & 0.50 & 0.75 & 0.13 & 0.38 & 0.38 & 0.13 & 0.13 & 0.25 \\
\hline Semi-evergreen forest & 0.29 & 0.86 & 0.67 & 0.05 & 0.57 & 0.14 & 0.76 & 0.67 & 0.14 & 0.10 & 0.57 \\
\hline Mesquite forest & 0.43 & 0.57 & 0.43 & 0.14 & 0.29 & 0.14 & 0.29 & 0.43 & 0.14 & 0.00 & 0.00 \\
\hline Overall error rate & 0.23 & 0.51 & 0.47 & 0.31 & 0.53 & 0.14 & 0.46 & 0.36 & 0.13 & 0.07 & 0.28 \\
\hline Kappa & 0.69 & 0.32 & 0.37 & 0.58 & 0.30 & 0.81 & 0.39 & 0.51 & 0.82 & 0.90 & 0.63 \\
\hline
\end{tabular}

*HMAD, H90th, CDENSITY2, HMAX, H75th, CDENSITY3, STRAT2.

$\uparrow$ NDVI, TCAP-W, TCAP-G.

\$NDVI, TCAP-W, TCAP-G, TCAP-B.

§CURV, IMI, CTI, SRAD, SLP.

๑SRAD, CURV, SLP, ASP.

**CURV, CDENSITY2, HMAD, H90th, CTI, CDENSITY3, SLP, HMAX, H75th, STRAT2, HMEDIAN, CDENSITY1, STRAT1.

††NDVI(wet), TCAP-W(dry), TCAP-G(wet), TCAP-W(wet), $\Delta$ TCAP-B, NDVI(dry), TCAP-G(dry), $\Delta \mathrm{B} 2, \Delta \mathrm{B} 5$.

ttNDVI(wet), TCAP-G(wet), TCAP-W(dry), NDVI(dry), TCAP-W(wet), $\Delta B 2, \Delta$ TCAP-B, TCAP-G(dry), CURV, $\Delta B$ 5, TCAP-B(wet), SLP, ASP, $\Delta B 1$, CTI.

§§URV, HMAD, H90th, CDENSITY2, CTI, HMAX, H75th, CDENSITY3, B2(wet), STRAT2, TCAP-G(wet), SLP, HMEDIAN, TCAP-W(wet).

qฯCURV, ELEV, DIST, HMAD, CDENSITY2, H90th, CTI, CDENSITY3.

***ELEV, DIST, NDVI(wet), TCAP-W(dry), TCAP-G(wet), TCAP-W(wet), NDVI(dry), $\Delta$ TCAP-B, $\Delta \mathrm{B} 2$, CURV,

TCAP-G(dry), SLP, $\triangle B$ 5, TCAP-B(wet), CTI, ASP. 
Eastern portion $\left(0.05\right.$ pulses $\left./ \mathrm{m}^{2}\right)$. We then used an algorithm (Evans \& Hudak 2007) to classify the LiDAR data into ground versus canopy returns, and calculated a suite of canopy metrics at a 30-m grid size (see Table 2). We considered any return $>30 \mathrm{~cm}$ above the ground to be vegetation, avoiding confusion with limestone outcrops. As most vegetation returns (i.e., 95\%) were first or single returns, the metrics of canopy density by this study (calculated as \# of vegetation returns above a specific height $\times$ $100 /$ total number of returns, within each $30 \times 30 \mathrm{~m}$ grid cell) can be used also as a physical measure of canopy cover (i.e., horizontal structure).

We calibrated the Landsat data to reflectance values and then applied a radiometric normalization method Canty and Nielsen (2008) using ENVI 4.5 (ITT Visual Information Solutions ${ }^{\circledR}$, Boulder, Colorado, U.S.A.). We calculated the NDVI and the Tasseled Cap transformation for the two scenes. The Tasseled Cap (Kauth \& Thomas 1976) reduces the image data to three ecologically meaningful bands or indices of brightness, greenness, and wetness, which have been shown useful for separating successional stages and forest types (e.g., Cohen et al. 1995, Helmer et al. 2000, Song et al. 2007). Finally, we calculated differences in the band spectral values and indices between the two image dates (Table 2).

We horizontally co-registered the $30 \mathrm{~m}$ SRTM DEM to the $30 \mathrm{~m}$ LiDAR DEM and calculated a suite of topographic variables from both DEMs using ArcGIS 9.2 (ESRI ${ }^{\circledR}$, Redlands, California, U.S.A.) Spatial Analyst (Table 2). Finally, we created a GIS layer quantifying the distance from the coast.

DATA ANALYSIS.-We used classification-tree techniques, which have been successfully applied in tropical deciduous ecosystems
(Krishnaswamy et al. 2004). For the first objective, we used the Random Forest (RF) algorithm (Breiman 2001), implemented in R (Liaw \& Wiener 2002, R Development Core Team 2005), which is a bootstrap-based extension of classification-tree methods that has shown excellent results in ecological and remote sensing studies (e.g., Lawrence et al. 2006, Cutler et al. 2007, Martinuzzi et al. 2009). Classification rules are developed by combining hundreds to thousands of classification trees, constructed from random subsets of the training data and explanatory variables. The algorithm provides an internal measure of misclassification error (using observations that are randomly withheld in each tree development), eliminating the need for a secondary data set for accuracy assessment (Breiman 2001, Lawrence et al. 2006, Falkowski et al. 2009). The algorithm provides also measures of variable importance (derived from the permutation of the independent variables), which can be used to compare with ecological expectations based on literature (Cutler et al. 2007). We identified the most parsimonious model using a RF-based method by Murphy et al. (2010), which iteratively reduces the number of variables using the variable's importance measure.

We classified forest types in two ways, first using single sources of remotely sensed explanatory variables (e.g., LiDAR canopy alone) and then by combining multiple data sources (e.g., LiDAR canopy plus LiDAR DEM). The variables Elevation (ELEV) and Distance to the coast (DIST) were added at the end, in a separate new model. This is because the importance of these variables appears to be too specific to Guánica (i.e., they explain much of the distribution of the mesquite and dwarf forest). Therefore, creating classification models with and without

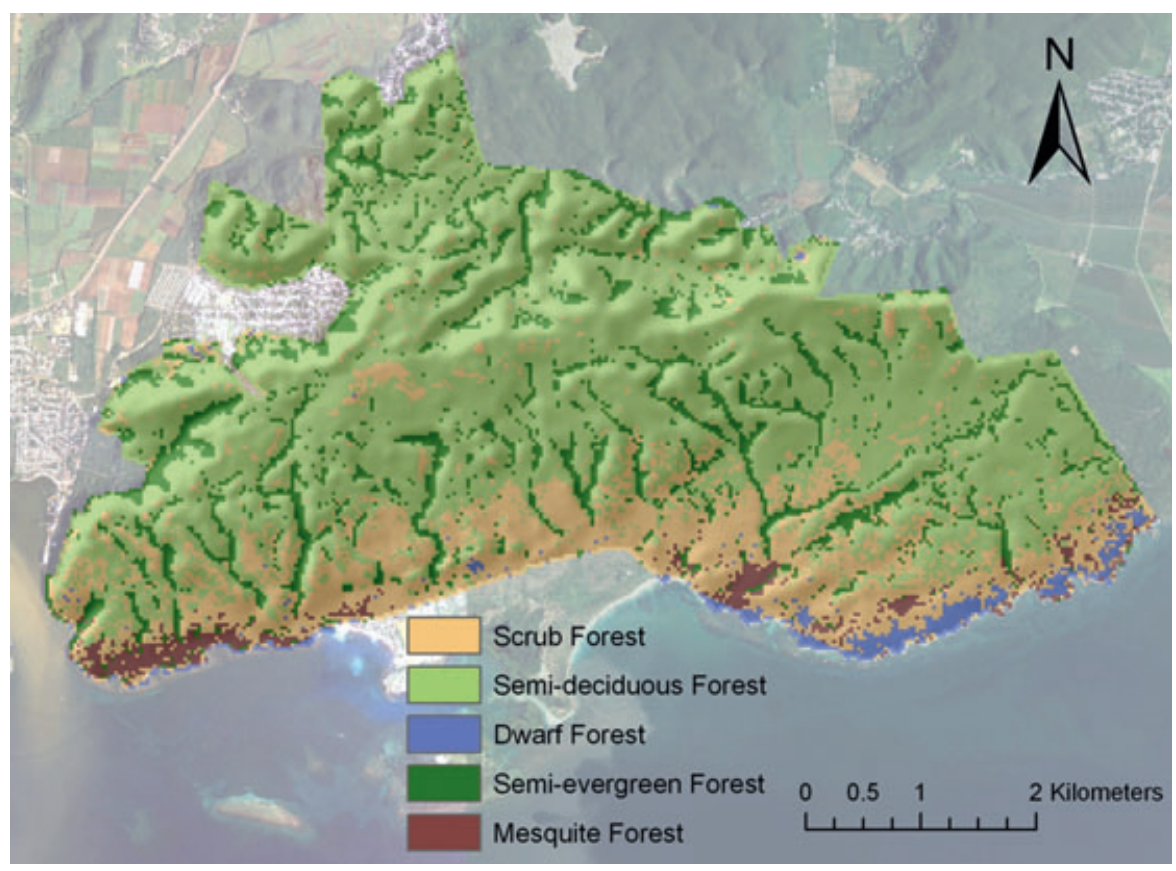

FIGURE 1. Map of five forest types for the Guánica Biosphere Reserve (Puerto Rico) derived from LiDAR data (spatial resolution = 30 m). 
ELEV and DIST allowed us to better transfer our findings to other areas.

Classification trees were applied differently in classifying forest succession. As the sample size was smaller $(N=25$ and restricted to semi-deciduous forests), we were able to partition the data manually. We developed decision trees using the smallest number of binary partitions possible to explain the data (three splits; i.e. \# of land-use history classes - 1). We compared the results of using LiDAR canopy metrics versus Landsat multiseason imagery. Topography was not included because it is not a major variable explaining variations in forest structure within semi-deciduous forests (Agosto Diaz 2008). For all the classifications made, we reported global and class-level errors rates (ranging from 0 to 1) and the kappa statistic (Landis \& Koch 1977), which measures overall classification accuracy compensating for agreement due to chance (where a value of 1.0 denotes perfect agreement and 0.0 no agreement other than that which would be expected by chance alone). Kappa values ranging between $0.41-0.60,0.61-0.80$, and $0.81-0.99$ describe moderate, substantial, and almost perfect accuracies, respectively (Landis \& Koch 1977).

\section{RESULTS}

We first classified forest types using one source of remotely sensed explanatory variables. The classification using LiDAR can- opy metrics alone yielded the highest accuracy (kappa $=0.69$ ), followed by the LiDAR DEM metrics (kappa $=0.58$; Table 3). The classifications using Landsat or STRM DEM data, on the other hand, had kappa values ranging between 0.30 and 0.37 . The classification from the LiDAR DEM had a higher accuracy than the classification from SRTM DEM (kappa values of 0.58 and 0.30 , respectively). In these two models, the semi-evergreen forest showed the largest error difference, with a misclassification rate of 0.05 from the LiDAR DEM versus 0.57 from the SRTM DEM. Finally, classification accuracies from the two Landsat scenes were very similar (kappa values of 0.37 and 0.32 ).

The most important predictors in the LiDAR canopy model included the median absolute deviation of vegetation heights (HMAD), the 90th percentile of vegetation heights (H90th), and the percent of returns $>1.0 \mathrm{~m}$ (CDENSITY2; Table 3). The NDVI and the wetness and greenness indices were important in the Landsat-based models. Finally, the variable curvature (CURV) appeared among the most important variables in the classifications using topographic data.

The combination of the two different sources of LiDAR explanatory variables (i.e., canopy and topographic metrics) reduced the error from 0.23 (observed using LiDAR canopy metrics alone) to 0.14 , resulting in a kappa statistic of 0.81 (Table 3). The class-level errors ranged between 0.13 and 0.16 . On the other hand, combining the two Landsat seasons did not substantially improve the classification accuracy over the dry season

\section{LiDAR based classification}

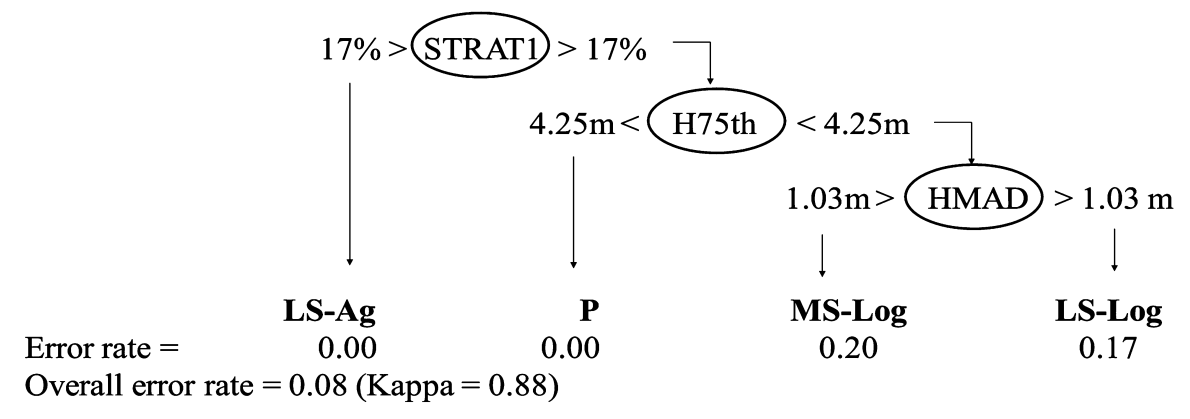

\section{Landsat based classification}

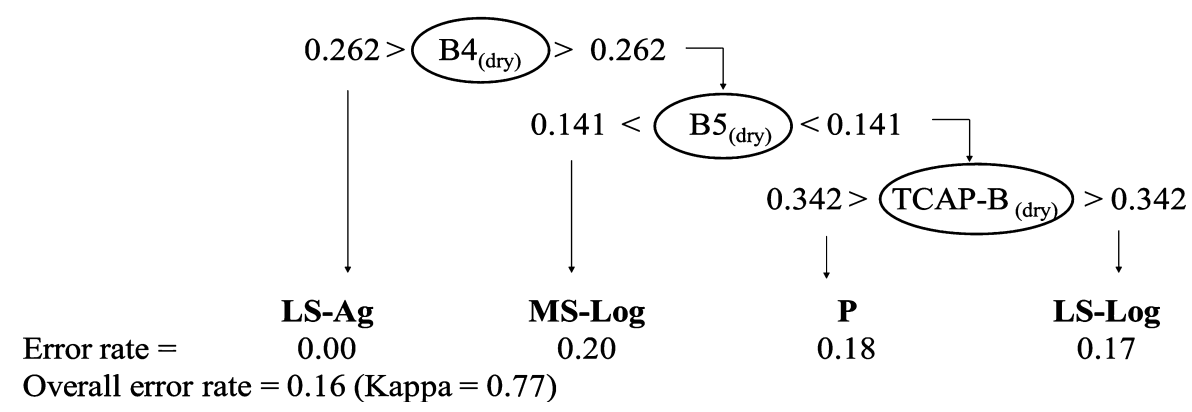

FIGURE 2. Classification-tree decisions and resultant accuracy statistics for forest successional classification using LiDAR (top) or Landsat ETM+ (bottom) data. Mid-secondary forest with logging past (MS-Log); late-secondary forest with logging past (LS-Log); late-secondary forest with agricultural past (LS-Ag); primary forest $(\mathrm{P})$. 
imagery alone (kappa values of 0.39 and 0.37 , respectively). The class-level errors for the Landsat multi-season classification ranged between 0.21 and 0.76 , with two of the three most extensive forest types in Guánica (i.e., semi-deciduous and semi-evergreen) $>0.40$.

The addition of SRTM topographic variables to the multidate Landsat model increased the classification accuracy from a kappa of 0.39 observed in the Landsat-only model to 0.51 (Table 3). The class-level error ranged between 0.21 and 0.67 , with the largest error found in the semi-evergreen forest. Finally, the addition of Landsat variables did not improve the accuracy observed using LiDAR explanatory variables (canopy plus DEM; i.e., kappa 0.82 vs. 0.81). The variables included in the models developed from multiple sources of remotely sensed based explanatory variables were typically a combination of the most important variables observed in the models using one source at a time.

Adding the variables elevation (ELEV) and distance to the coast (DIST) improved the classification accuracy. The kappa value increased from 0.81 to 0.90 in the LiDAR-based model, and from 0.51 to 0.63 in the Landsat-SRTM one (Table 3). The final models included ELEV and DIST in addition to other variables that were important in the previous classifications. The resultant LiDAR-based map of forest types for Guánica is shown in Figure 1.

In addressing our second objective, we classified past land use within the semi-deciduous forest using LiDAR (canopy) versus Landsat variables (Fig. 2). The model constructed from LiDAR had the highest accuracy (kappa values of 0.88 and 0.77 , respectively), and both models separated the mid- and late-secondary forest classes equally. The LiDAR-based model, however, separated the primary forests perfectly (i.e., error rate $=0.00$ ) while the Landsat- based models produced some confusion (error rate $=0.18)$. The three explanatory variables included in the LiDAR-based model included the percentage of vegetation returns between 0.3 and $3 \mathrm{~m}$ (STRAT1), the 75th percentile of vegetation heights $(\mathrm{H} 75 \mathrm{th})$, and the median absolute deviation of
H90th (in meters)

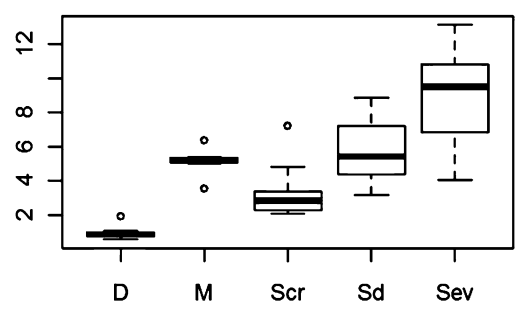

CURV (LiDAR)

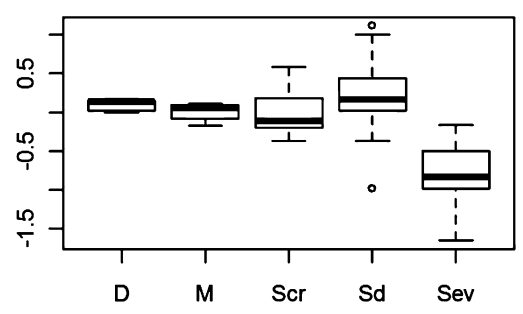

NDVI(dry)

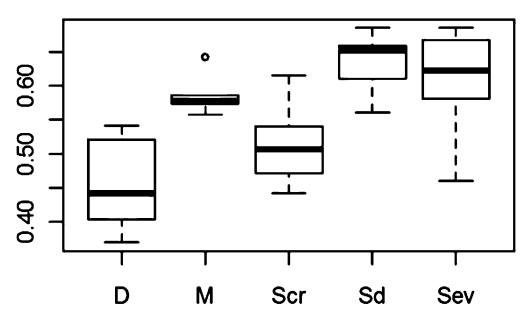

CDENSITY2 (in \%)

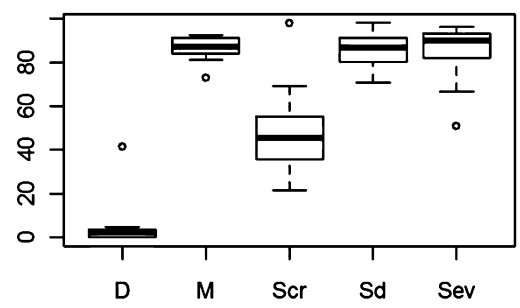

CURV (SRTM)

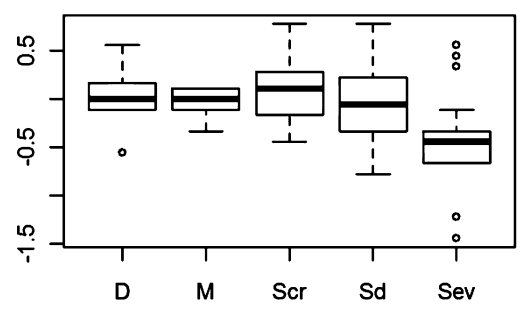

NDVI(wet)

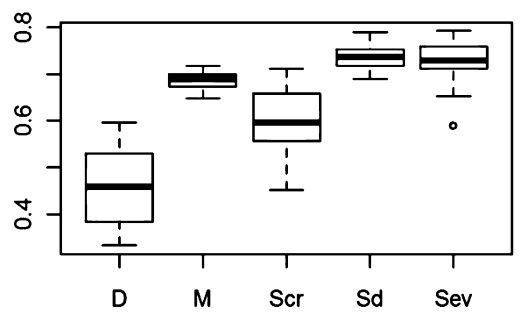

HMAD (in meters)

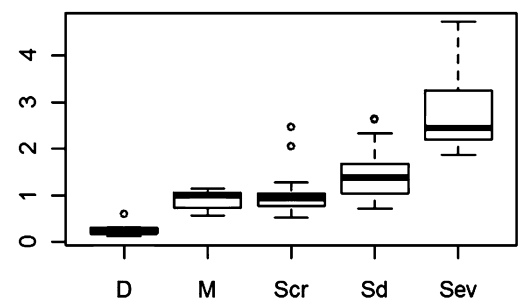

ELEV (in meters)

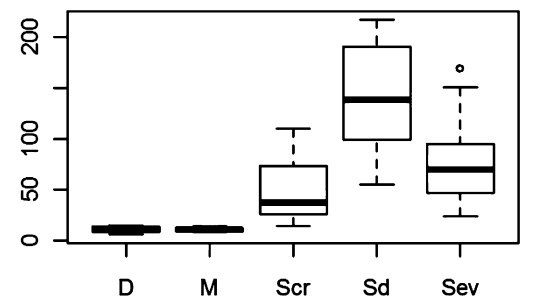

NDVI(difference)

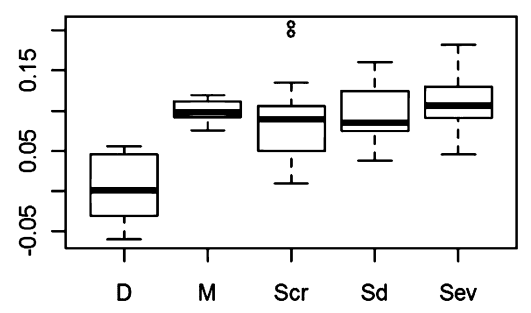

FIGURE 3. Remotely sensed predictor variables in different forest types, including: semi-deciduous forest (Sd), semi-evergreen (Sev), scrub forest (Scr); mesquite (M), and coastal dwarf forest (D). 
vegetation heights (HMAD; Fig. 2). On the other hand, the Landsat-based model included Band 4, Band 5, and the Brightness index, all from the dry season.

\section{DISCUSSION}

Our study explored the use of LiDAR data to classify tropical dry forest types and succession. We found that LiDAR data were powerful predictors of tropical dry forest types, achieving higher accuracies than classifications made from previously available remote sensing data (i.e., Landsat and SRTM). The best results were obtained when combining LiDAR-derived information of canopy structure and topography. As a result, forest types that have been difficult to separate in previous efforts using Landsat imagery (e.g., Helmer et al. 2002, 2008, Gould et al. 2008, Martinuzzi et al. 2008) were possible to separate using LiDAR.

In addition, we detected no enhanced value for classifying forest types in Guánica after integrating Landsat with LiDAR data. In fact, a misclassification rate of 0.14 when using LiDAR data alone (and 0.07 when adding the variables elevation and distance to the coast; Table 3) yields little room for improvement. Expanding to other land cover types is important to better understand the role of LiDAR in tropical dry forest regions.

Scientists have long shown that Guánica forests vary in terms of canopy height, canopy cover and vertical complexity, and that their geographic distribution is profoundly affected by soil conditions (see Lugo 2005). The most important LiDARderived predictors seem to reflect those variations, providing a novel picture of the vegetation (Fig. 3). The metric H90th, for example, tends to correspond well with the mean tree height of a stand (Hopkinson et al. 2006, Li 2009). We likewise observed an increase in canopy height from dwarf forest to the scrub forest, semi-deciduous and mesquite, and finally to the semi-evergreen forest, with median values of about $1,3,5$, and $10 \mathrm{~m}$ that match the general descriptions found in the literature (see Lugo 2005, Agosto Diaz 2008). The metric CDENSITY2, a surrogate of canopy cover in this study, showed that well-developed forests such as the semi-deciduous, semi-evergreen, and mesquite have high canopy cover (e.g., $>70 \%$ for the semi-deciduous and consistent with Murphy and Lugo [1986]), whereas the naturally open scrub forest reported much lower values, as expected (Fig. 3). The fact that the dwarf forest appeared with little or no canopy cover is an artifact of the threshold established at $>1 \mathrm{~m}$, above which little or no vegetation exists for this forest type. Finally, the metric HMAD (median absolute deviation of vegetation heights) seems to reflect known patterns of vertical heterogeneity. In this sense, the semi-evergreen is the most structurally diverse forest type in Guánica because it supports the largest variations in tree height and diameter, followed by the semi-deciduous forest (Lugo 2005). In our study, the semi-evergreen and semideciduous forest types showed the first and second largest HMAD values, respectively (see Fig. 3).

Distinctive characteristics of the invasive mesquite forest also related to the HMAD LiDAR metric. Our study showed that the mesquite forest is similar to the semi-deciduous forest in terms of horizontal structure and height (i.e., Wilcoxon Test $[\mathrm{W}]=87.5, P$-value $=0.68$ for CDENSITY2; $\mathrm{W}=107.5, \quad P$ value $=0.71$ for H90th). This exotic-dominated forest, however, appeared less vertically diverse (in HMAD values) than the semideciduous forest $(\mathrm{W}=167, P$-value $=0.005$; see Fig. 3 ). This might be a result of the different number of tree strata naturally present in these two forest types, i.e., one for the mesquite (Stromberg 1993) versus one to three for the semi-deciduous (Lugo 2005). This difference in the number of strata might cause the laser returns to be more scattered along the vertical dimension, resulting in different HMAD values. Our findings agree with Asner et al. (2008a, b) who found that exotics can transform the $3 \mathrm{D}$ structure of the forest, and that LiDAR can be sensitive to those transformations. Furthermore, we observed little variation in H90th values within the mesquite stand (Fig. 3), suggesting a tree cohort established likely after a single disturbance event (e.g., agricultural abandonment) rather than
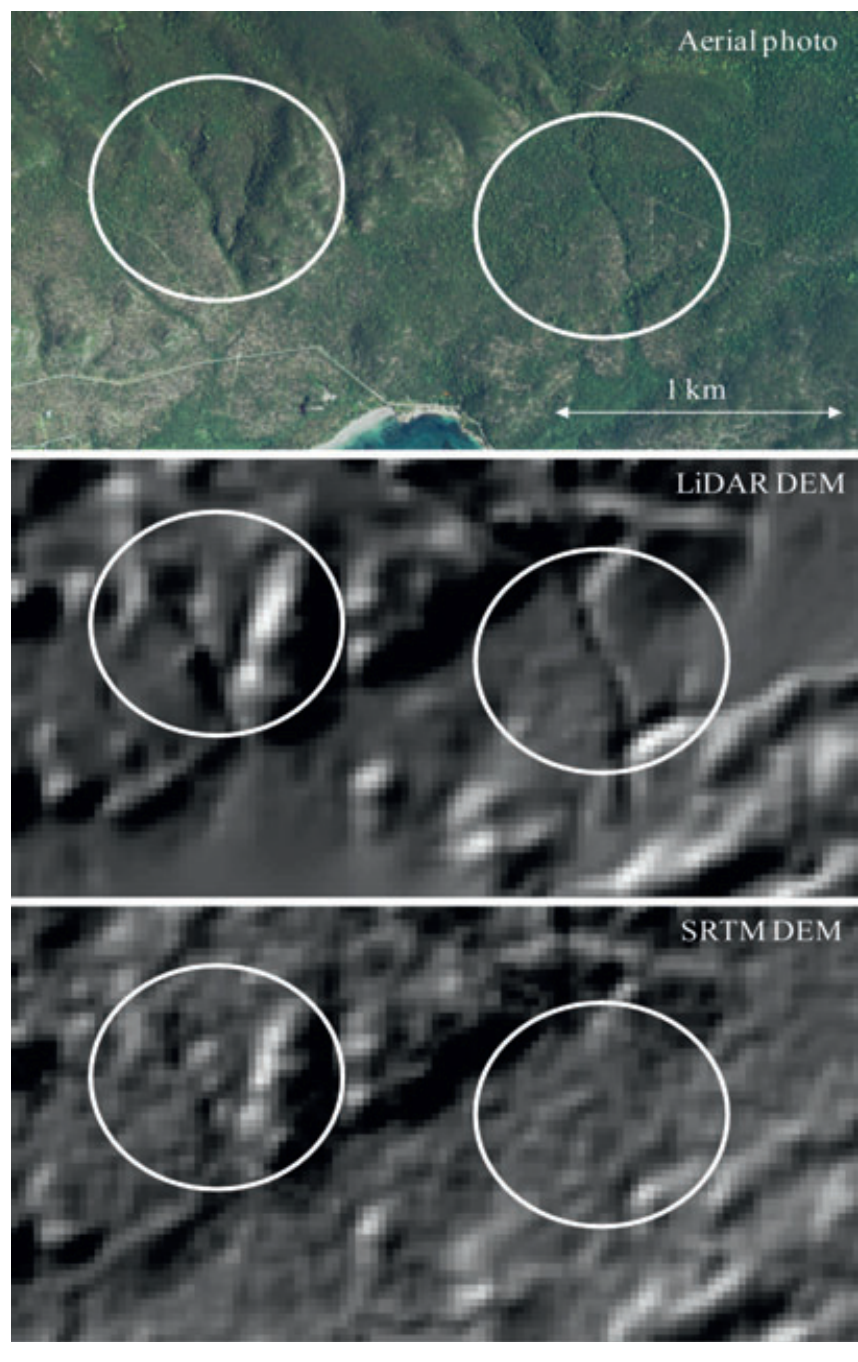

FIGURE 4. Topographic detail captured by the $30-\mathrm{m}$ pixel digital elevation models from LiDAR versus SRTM. Examples of small valleys and ravines as highlighted with circles. 
gradual recruitment over time (therefore providing insights about the processes of invasion). Finally, a recent field visit to other areas mapped as mesquite forests revealed the presence of mixed mesquite/semi-deciduous forest patches in the eastern part, and some level of overestimation in the west.

Topographic (i.e., DEM-based) variables were important for refining the classification of tropical dry forest types, agreeing with Helmer et al. 2008, Martinuzzi et al. 2008, and Sesnie et al. 2008. Although both LiDAR and SRTM DEMs added predictive power to the classifications, the LiDAR DEM did a better job in discriminating forest types. This difference was largely attributed to the semi-evergreen forest, which was better separated using the LiDAR DEM. We believe that this is a result of a lower ability of SRTM data to depict topographic changes under forest canopies. Although LiDAR returns can reach the true ground even under very dense forest canopies (Hofton et al. 2002), elevations retrieved from SRTM are located somewhere between the canopy top surface and the ground (Hofton et al. 2006). As a result, valleys and ravines, which are the distinctive locations of semi-evergreen forests, were better defined in the LiDAR DEM than in the SRTM DEM (see Fig. 4). In these areas, the lower surface elevations might be canceled by the simultaneous presence of taller forests, resulting in a final SRTM elevation that is not very different from the nearest cells. The better separation of semi-evergreen forests with the LiDAR-derived curvature (i.e., CURV, which describe convexity and concavity of slope profiles with positive and negative values, respectively) reinforces the previous point (Fig. 3).

LiDAR metrics of canopy structure were useful for separating mid- and late-secondary forests, as well as primary forests. Identifying these habitats is critical for conservation and management, yet has been difficult in previous studies. We observed that the LiDAR variables that best classified succession were those describing vertical canopy structure (rather than horizontal, i.e., STRAT1, H75th, and HMAD). This supports the idea that horizontal structure might have stabilized in these mature forests,

\section{H75th (in meters)}

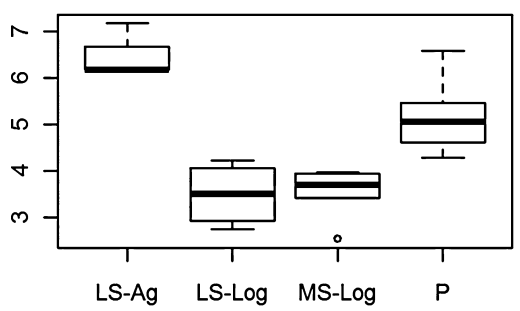

NDVI(dry)

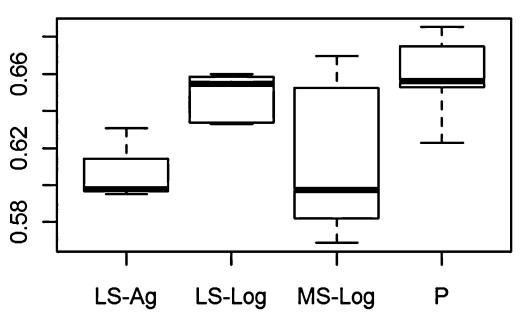

CDENSITY2 (in \%)

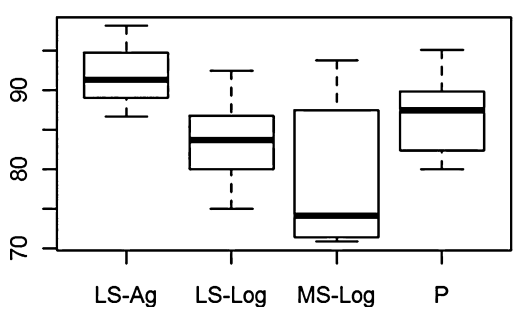

HMAD (in meters)

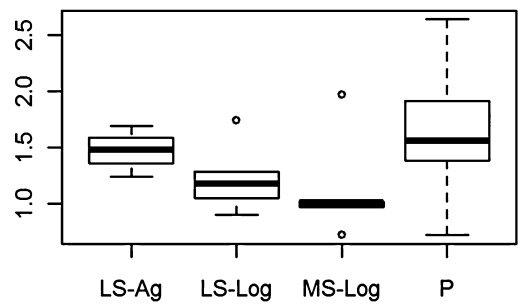

NDVI(wet)

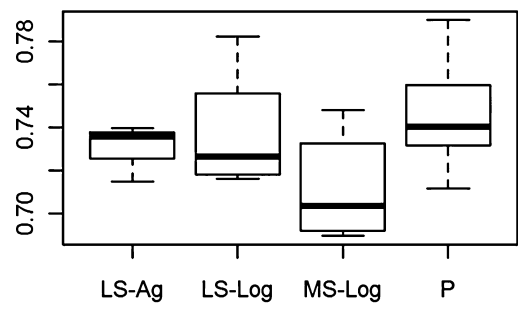

Brightness(dry)

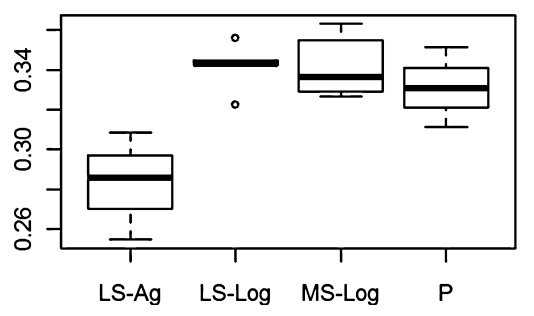

STRAT1 (in meters)

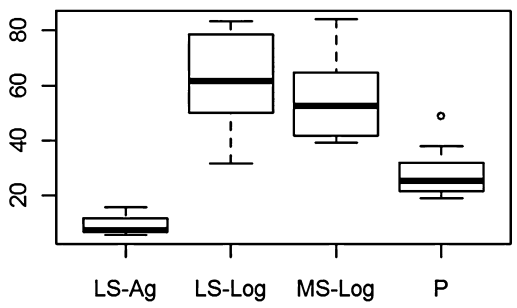

NDVI(difference)

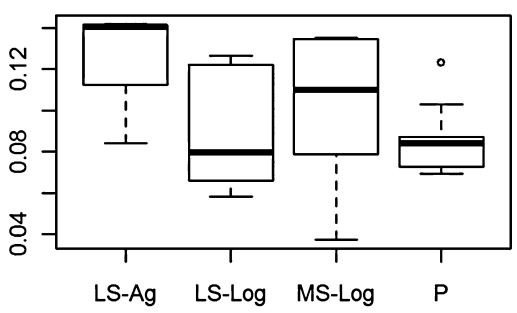

B5(dry)

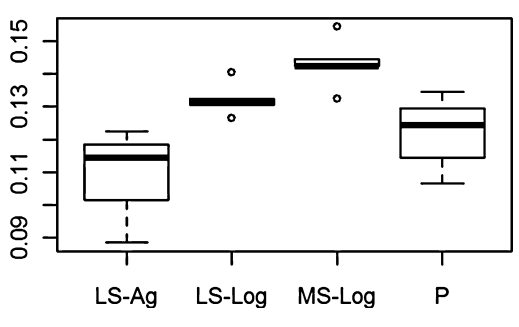

FIGURE 5. Remotely sensed predictor variables in different succesional classes, including: mid-secondary forest with logging past (MS-Log); late-secondary forest with logging past (LS-Log); late-secondary forest with agricultural past (LS-Ag); and primary forest (P). 
whereas changes in the vertical dimension might still be occurring as forest ages (Lugo 2005). Although more research is needed to better understand the biophysical meaning of these metrics, our findings reinforced the value of LiDAR to assess succession and land-use legacy (Falkowski et al. 2009). Finally, the fact that an exotic species (Leucaena leucocephala) dominates forest recovery in one of the past land uses perfectly classified (i.e., the one with agricultural history), adds further value to use of LiDAR for assessing novel forests. Expanding and testing succession assessments in other tropical dry forest types and land-use histories are warranted.

Our findings provide also valuable information for further applications using optical imagery (e.g., Landsat). For instance, our study supported the use of dry season imagery to assess succession in tropical dry forests, similar to Arroyo-Mora et al. (2005) and Kalacska et al. (2007). We found that the variables that appeared useful for classifying succession in our mature forests (i.e., Landsat bands 4, 5, and brightness, achieving a kappa of 0.77 ), however, were different to those identified previously in younger forests, i.e., NDVI (see Arroyo-Mora et al. 2005 and Hartter et al. 2008). This might be related to the fact that NDVI captures differences in horizontal structure between successional stages, but these are more evident in younger forests than in mature ones (Kalacska et al. 2005, Lugo 2005). As a result, the successional classes investigated in this study showed very similar NDVI and canopy cover values (CDENSITY2; Fig. 5). Finally, the variables identified by this study were consistent with Helmer et al. (2002), assessing succession in other tropical forests. Recently, advances have been made with the use of high-spatial resolution imagery and multi-scale approaches (see Gallardo-Cruz et al. 2012).

Our study highlights the value of LiDAR data — even low density LiDAR - for assessing tropical dry forests, and complements recent findings by Kennaway et al. (2008), Castillo-Nuñez et al. (2011), and Castillo et al. (2012). Our results are in agreement with work from a wide variety of forested ecosystems indicating that LiDAR data provide predictor variables that afford unique explanatory power to describe landscape patterns and processes (e.g., Kellner et al. 2011). For example, in a growing number of studies, LiDAR canopy and topography metrics have been shown to afford predictive power that is either on par with, or exceeds, that of conventional passive multi-spectral remote sensing data (e.g., Hyde et al. 2005, Goetz et al. 2007, Vogeler et al. in review, this study) and field-collected data (e.g., Vierling et al. 2011a) in explaining ecological attributes of forest biodiversity, animal species' habitats (Vierling et al. 2008), and vegetation structure. However, passive data remain indispensable for ecological study: continued advances in spectral, spatial, and temporal resolution of passive remote sensing data, in addition to time series analysis of existing archival data (e.g., Kennedy et al. 2007, Krishnaswamy et al. 2009), will continue to provide a rich set of products that can be merged with LiDAR-based analyses. As LiDAR data sets become more prevalent and widely employed in a variety of scientific, management, and other contexts (Stoker et al. 2008, Vierling et al. 2011b), such fusion between LiDAR and passive remote sensing data is becoming more feasible to not only analyze the status of ecosystems for a single date, but to quantify dynamic change through time (Dubayah et al. 2010, Hudak et al. 2012).

\section{ACKNOWLEDGMENTS}

This study was funded by the USGS Gap Analysis Program. E. Næsset, M. Falkowski, and J. Stoker provided valuable inputs in early stages of this study. R. Agosto, E. Medina, J. Chinea, and S. Van Bloem facilitated field information. Technical support was provided by the University of Idaho, the U.S. Forest Service Moscow Forest Science Laboratory and the U.S. Forest Service IITF. Study at IITF is conducted in collaboration with the University of Puerto Rico.

\section{SUPPORTING INFORMATION}

Additional Supporting Information may be found in the online version of this article:

FIGURE S1. Location of the study area in Southwestern Puerto Rico.

Please note: Wiley-Blackwell are not responsible for the content or functionality of any supporting materials supplied by the authors. Any queries (other than missing material) should be directed to the corresponding author for the article.

\section{LITERATURE CITED}

Agosto Diaz, R. E. 2008. Human and environmental factors explaining the structural and compositional variability in a sub-tropical dry forest. MSc dissertation, University of Puerto Rico, 55 pp.

Antonarakis, A. S., K. S. Richards, and J. Brasington. 2009. Object-based land cover classification using airborne LiDAR. Remote Sens. Environ. 112: 2988-2998.

Arroyo-Mora, J. P., G. A. Sánchez-Azofeifa, M. E. R. Kalacska, B. Rivard, J. C. Calvo-Alvarado, and D. H. Janzen. 2005. Secondary forest detection in a Neotropical dry forest landscape using Landsat 7 ETM + and Ikonos imagery. Biotropica 34: 497-507.

Asner, G. P., R. F. Hughes, P. M. Vitousek, D. E. Knapp, T. KennedyBowdoin, J. Boardman, R. E. Martin, M. Eastwood, and R. O. GreEN. 2008a. Invasive plants transform the three-dimensional structure of rain forests. Proc. Natl. Acad. Sci. U.S.A. 18: 4519-4523.

Asner, G. P., M. O. Jones, D. E. Knapp, T. Kennedy-Bowdoin, M. O. Jones, R. E. Martin, J. W. Boardman, and C. B. Field. 2007. Carnegie airborne observatory: In-flight fusion of hyperspectral imaging and waveform light detection and ranging for three-dimensional studies of ecosystems. J. Appl. Remote Sens. 1: 013536, [Online: doi 10.1117/1111.2794018].

Asner, G. P., D. E. Knapp, T. Kennedy-Bowdoin, M. O. Jones, R. E. MarTIN, J. BoARdman, AND R. F. Hughes. 2008b. Invasive species detection in Hawaiian rainforests using airborne imaging spectroscopy and LiDAR. Remote Sens. Environ. 112: 1942-1955.

Breiman, L.. 2001. Random forests. Mach. Learning 45: 5-32.

Canty, M. J., And A. A. Nielsen. 2008. Automatic radiometric normalization of multitemporal satellite imagery with the iteratively re-weighted MAD transformation. Remote Sens. Environ. 112: 1025-1036.

Castillo, M., B. Rivard, A. Sánchez-Azofeifa, J. Calvo-Alvarado, and R. O. Dubayah. 2012. LiDAR remote sensing for secondary Tropical Dry Forest identification. Remote Sens. Environ. 121: 132-143. 
Castillo-Nuñez, M., G. A. Sánchez-Azofeifa, A. Croitoru, B. Rivard, J. Calvo-Alvarado, and R. O. Dubayah. 2011. Delineation of secondary succession mechanisms for tropical dry forests using LiDAR. Remote Sens. Environ. 115: 2217-2231.

Chazdon, R. L., C. A. Peres, D. Dent, D. Sheil, A. E. Lugo, D. Lamb, N. E. Stork, E. Nigel, AND S. E. Miller. 2009. The potential for species conservation in tropical secondary forests. Conserv. Biol. 23: 1406-1417.

Cohen, W. B., And S. N. Goward. 2004. Landsat's role in ecological applications of remote sensing. Bioscience 54: 535-545.

Cohen, W. B., T. A. Spies, and M. Fiorella. 1995. Estimating the age and structure of forests in a multi-ownership landscape of western Oregon, U.S.A. Int. J. Remote Sens. 16: 721-746.

Cutler, R. D., T. C. Edwards Jr, K. H. Beard, A. Cutler, K. T. Hess, J. GibSON, AND J. J. LAWLER. 2007. Random forests for classification in ecology. Ecology 88: 2783-2792.

Drake, J. B., R. O. Dubayah, D. B. Clark, R. G. Knox, J. B. Blair, M. A. Hofton, R. L. Chazdon, J. F. Weishampel, and S. D. Prince. 2002. Estimation of tropical forest structural characteristics using large-footprint lidar. Remote Sens. Environ. 79: 305-319.

Dubayah, R. O., S. L. Sheldon, D. B. Clark, M. A. Hofton, J. B. Blair, G. C. Hurtt, and R. L. Chazdon. 2010. Estimation of tropical forest height and biomass dynamics using lidar remote sensing at La Selva, Costa Rica. J. Geophys. R. 15: G00E09.

Evans, J. S., AND A. T. HudAK. 2007. A multiscale curvature algorithm for classifying discrete return LiDAR in forested environments. IEEE Trans. Geosci. Remote Sens. 45: 1029-1038.

Falkowski, M. J., J. S. Evans, S. Martinuzzi, P. E. Gessler, and A. T. HuDAK. 2009. Characterizing forest succession with Lidar data: An evaluation for the Inland Northwest USA. Remote Sens. Environ. 113: 946-956.

Farnsworth, E. J., 1993. Ecology of semi-evergreen plant assemblages in the Guánica dry forest, Puerto Rico. Caribb. J. Sci. 29: 106-123.

Feeley, K. J., T. W. Gillespie, And J. Terbough. 2005. The utility of spectral indices from Landsat ETM+ for measuring the structure and composition of tropical dry forests. Biotropica 37: 508-519.

Gallardo-Cruz, J. A., J. A. Meave, E. J. Gonzáles, E. E. Lebrija-Trejos, M. A. Romero-Romero, E. A. Perez-Garcia, R. Gallardo-Cruz, J. L. Hernandez-Stefanoni, and C. Martorell. 2012. Predicting tropical dry forest successional attributed from space: Is the key hidden in image texture? PLoS One 7: e30506.

Gessler, P. E., I. D. Moore, N. J. McKenzie, And P. J. Ryan. 1995. Soil-landscape modeling and spatial prediction of soil attributes. Int. J. Geogr. Inf. Syst. 9: 421-432.

Goetz, S., D. Steinberg, R. Dubayah, and B. Blair. 2007. Laser remote sensing of canopy habitat heterogeneity as a predictor of bird species richness in an eastern temperate forest, USA. Remote Sens. Environ. 108: 254-263.

Gould, W. A., C. Alarcón, B. Fevold, M. E. Jiménez, S. Martinuzzi, G. Potts, M. Quiñones, M. Solórzano, and E. Ventosa. 2008. The Puerto Rico Gap Analysis Project - volume 1: Land cover, vertebrate species distributions and land stewardship. US Forest Service IITFGTR-39, Río Piedras, Puerto Rico, 165 pp.

Hartter, J., C. Lucas, A. E. Gaughan, and L. L. Aranda. 2008. Detecting tropical dry forest succession in a shifting cultivation mosaic of the Yucatán Peninsula, Mexico. Appl. Goegr. 28: 134-149.

Helmer, E. G., S. Brown, And W. B. Cohen. 2000. Mapping montane tropical successional stage and land use with multi-date Landsat imagery. Int. J. Remote Sens. 21: 2163-2183.

Helmer, E. H., T. A. Kennaway, D. H. Pedreros, M. L. Clark, H. MarcanoVega, L. L. Tieszen, T. R. Ruzycki, S. R. Schild, and C. M. S. CarringTON. 2008. Land cover and forest formation distributions for St. Kitts, Nevis, St. Eustatius, Grenada and Barbados from decision tree classification of cloud-cleared satellite imagery. Caribb. J. Sci. 44: 175-198.

Helmer, E. H., O. R. Ramos, T. M. López, M. Quiñones, and W. Diaz. 2002. Mapping forest type and land cover of Puerto Rico, a compo- nent of the Caribbean biodiversity hotspot. Caribb. J. Sci. 38: 165183.

Hill, R. A., AND J. SuArez. 2010. SilviLaser: Applications of laser systems for forest assessment and inventory. Int. J. Remote Sens. 31: 1129-1132.

Hill, R. A., And A. G. Thomson. 2005. Mapping woodland species composition and structure using airborne spectral and LiDAR data. Int. J. Remote Sens. 26: 3763-3779.

Hofton, M., R. Dubayah, J. B. Blair, and D. Rabine. 2006. Validation of SRTM elevations over vegetated and non-vegetated terrain using medium footprint lidar. Photogramm. Eng. Remote Sens. 72: 279-285.

Hofton, M. A., L. E. Rocchio, J. B. Blair, and R. Dubayah. 2002. Validation of large-footprint lidar sub-canopy topography. J. Geodyn. 34: 477489.

Hopkinson, C., L. Chasmer, K. Lim, P. Treitz, and I. Creed. 2006. Towards a universal lidar canopy height indicator. Can. J. Remote Sens. 32: $139-152$.

Hudak, A., E. Strand, L. Vierling, J. Byrne, J. Eitel, S. Martinuzzi, and M. FALKowski. 2012. Quantifying aboveground forest carbon pools and fluxes from repeat LiDAR surveys. Remote Sens. Environ. 123: 25-40.

Hyde, P., R. Dubayah, B. Peterson, J. B. Blair, M. Hofton, C. Hunsaker, R. KNOX, AND W. WALKER. 2005. Mapping forest structure for wildlife habitat analysis using waveform lidar: Validation of montane ecosystems. Remote Sens. Environ. 96: 427-43.

Iverson, L. R., M. E. Dale, C. T. Scott, and A. Prasad. 1997. A GiSderived integrated moisture index to predict forest composition and productivity of Ohio forests (U.S.A.). Landscape Ecol. 12: 331-348.

JANZEN, D. H. 1988. Tropical dry forests: The most endangered major ecosystem. In E. O. Wilson (Ed.). Biodiversity, pp. 130-137. National Academic Press, Washington, DC.

Kalacska, M., and A. SÁnchez-Azofeifa. 2008. Hyperspectral remote sensing of tropical and subtropical forests. Taylor and Francis Group, LCC, Boca Raton, Florida.

Kalacska, M. E. R., G. A. Sánchez-Azofeifa, J. C. Calvo-Alvarado, B. RiVARD, AND M. QUESADA. 2005. Effects of season and successional stage on leaf area index and spectral vegetation indices in three Mesoamerican tropical dry forests. Biotropica 37: 486-496.

Kalacska, M., G. A. Sánchez-Azofeifa, B. Rivard, T. Caeldi, H. P. White, and J. C. Calvo-Alvarado. 2007. Ecological fingerprint of ecosystem succession: Estimating secondary tropical dry forest structure and diversity using imaging spectroscopy. Remote Sens. Environ. 108: 8296.

KaUth, R. J., AND G. S. Thomas. 1976. The tasseled cap - a graphic description of the spectral-temporal development of agricultural crops as seen by Landsat. Proceedings on the Symposium on Macbine Processing of Remotely Sensed Data, 4b: 41-51, June 6 - July 2, West Lafayette, Indiana.

Keller, M., D. S. Schimel, W. W. Hargrove, and F. M. Hoffman. 2008. A continental strategy for the National Ecological Observatory Network. Front. Ecol. Environ. 6: 282-284.

Kellner, J. R., G. P. Asner, P. M. Vitousek, M. A. Tweiten, S. Hotchkiss, AND O. A. CHADwick. 2011. Dependence of forest structure and dynamics on substrate age and ecosystem development. Ecosystems 14: 1156-1167.

Kennaway, T., and E. H. Helmer. 2007. The forest types and ages cleared from land development in Puerto Rico. GISci. Remote Sens. 44: 356382.

Kennaway, T. A., E. H. Helmer, M. A. Lefsky, T. A. Brandeis, and K. R. SHERRILL. 2008. Mapping land cover and estimating forest structure using satellite imagery and coarse resolution lidar in the Virgin Islands. J. Appl. Remote Sens. 2: 023551.

Kennedy, R. E., W. B. Cohen, and T. A. Schroeder. 2007. Trajectory-based change detection for automated characterization of forest disturbance dynamics. Remote Sens. Environ. 110: 370-386.

Krishnaswamy, J., K. S. Bawa, K. N. Ganeshaiah, and M. C. Kiran. 2009. Quantifying and mapping biodiversity and ecosystems services: Utility 
of a multi-season NDVI and based Mahalanobis distance surrogate. Remote Sens. Environ. 113: 857-867.

Krishnaswamy, J., M. C. Kiran, and K. N. Ganeshaiah. 2004. Tree model based eco-climatic vegetation classification and fussy mapping in diverse tropical deciduous ecosystems using multi-season NDVI. Int. J. Remote Sens. 25: 1185-1205.

LANDIs, J. R., AND G. G. Косн. 1977. The measurement of observer agreement for categorical data. Biometrics 33: 159-174.

Lawrence, R. L., S. D. Wood, and R. L. Sheley. 2006. Mapping invasive plants using hyperspectral imagery and Breiman Cutler classifications (RandomForest). Remote Sens. Environ. 100: 356-362.

LI, Y. 2009. A comparison of forest height prediction from FIA field measurement and LiDAR data via spatial models. In W. McWilliams, G. Moisen, and R. Czaplewski (Eds.). 2008 Forest Inventory and Analysis (FIA) symposium; October 21-23, 2008: Park City, UT. Proc. RMRSP-56CD. U.S. Department of Agriculture, Forest Service, Rocky Mountain Research Station, Fort Collins, Colorado. 1 CD.

LiaW, A., AND M. Wiener. 2002. Classification and regression by RandomForest. R News 2: 18-22.

Lugo, A. E. 2005. Los Bosques. In R. Joglar (Ed.) Biodiversidad de Puerto Rico, pp. 395-548. Instituto de Cultura Puertoriqueña, San Juan, Puerto Rico.

Lugo, A. E. 2009. The emerging era of novel tropical forests. Biotropica 41: 589-591.

Lugo, A. E., J. A. Gonzalez-Liboy, B. Cintron, and K. Dugger. 1978. Structure, productivity, and transpiration of a subtropical dry forest in Puerto Rico. Biotropica, 10: 278-291.

Martinuzzi, S., W. A. Gould, O. M. Ramos Gonzalez, A. Martinez Robles, P. Calle Maldonado, N. Pérez-Buitrago, and J. J. Fumero Caban. 2008. Mapping tropical dry forest habitats integrating Landsat NDVI, Ikonos imagery, and topographic information in the Caribbean Island of Mona. Rev. Biol. Trop. 56: 625-639.

Martinuzzi, S., L. A. Vierling, W. A. Gould, M. J. Falkowski, J. S. Evans, A. T. Hudak, and K. T. Vierling. 2009. Mapping snags and understory shrubs for a LiDAR-based assessment of wildlife habitat suitability. Remote Sens. Environ. 113: 2533-2546.

Medina, E. and E. Cuevas. 1990. Propiedades fotosintéticas y eficiencia de uso de agua de plantas leñosas del bosque deciduo de Guánica: consideraciones generales y resultados preliminares. Acta Científica 4: $25-36$.

Molina Colón, S., ANd A. E. Lugo. 2006. Recovery of a subtropical dry forest after abandonment of different land uses. Biotropica 38: 354-364.

Murphy, P. G. And A. E. Lugo. 1986. Structure and biomass of a subtropical dry forest in Puerto Rico. Biotropica 18: 89-96.

Murphy, M. A., J. S. Evans, And A. S. Storfer. 2010. Quantifying Bufo boreas connectivity in Yellowstone National Park with landscape genetics. Ecology 91: 252-261.

Murphy, P. G., A. E. Lugo, A. J. Murphy, and D. C. Nepstad. 1995. The dry forests of Puerto Rico's south coast. In A. E. Lugo, and C. Lowe (Eds.). Tropical forests: management and ecology, pp. 178-209. Springer-Verlag, New York.

Neuenschwander, A. L., L. A. Magruder, and M. Tyler. 2009. Landcover classification of small-footprint, full-waveform lidar data. J. Appl. Remote Sens. 3: 033544, [Online: DOI:10.1117/1.3229944].
Quesada, M., G. A. Sánchez-Azofeifa, M. Alvarez-Añorve, K. E. Stoner, L. Avila-Cabadilla, J. Calvo-Alvarado, A. Castillo, M. M. Espirito Santo, M. Fagundes, G. W. Fernandes, J. Gamon, M. LopezaraikaMikel, D. Lawrence, L. P. Cerdeira Morellato, J. S. Powers, F. S. Neves, V. Rosas-Guerrero, R. Sayago, and G. Sanchez-Montoya. 2009. Succession and management of tropical dry forests in the Americas: Review and new perspectives. Forest Ecol. Manag. 258: 1014-1024.

R Development Core Team. 2005. R: A language and environment for statistical computing. R Foundation for Statistical Computing, Vienna, Austria. ISBN 3-900051-07-0. Available at: http://www.R-project.org (accessed 20 June 2011).

Rodríguez, E., C. S. Morris, And E. Belz. 2006. A global assessment of the SRTM performance. Photogramm. Eng. Remote Sens. 72: 249-260.

Sánchez-Azofeifa, G. A., K. L. Castro, B. Rivard, and M. R. Kalacska. 2003. Remote sensing research priorities in tropical dry forest environments. Biotropica 35: 134-142.

Sánchez-Azofeifa, G. A., K. L. Castro-Esau, W. A. Kurz, and A. Joyce. 2009. Monitoring carbon stocks in the tropics and the remote sensing operational limitations: From local to regional projects. Ecol. Appl. 19: 480-494.

Sánchez-Azofeifa, G. A., M. Quesada, J. P. Rodriguez, J. M. Nassar, K. E. Stoner, A. Castillo, T. Garvin, E. L. Zent, J. C. Calvo-Alvarado, M. E. R. Kalacska, L. Fajardo, J. A. Gamon, and P. Cuevas-Reyes. 2005. Research priorities for Neotropical dry forests. Biotropica 37: 477-485.

Sesnie, S. E., S. E. Hageld, S. M. Otterstrom, C. L. Chambers, and B. G. DICKSON. 2008. SRTM-DEM and Landsat ETM+ data for mapping tropical dry forest cover and biodiversity assessment in Nicaragua. Revista Geográfica Acadêmica 2: 53-65.

Song, C., T. A. Schroeder, And W. B. Cohen. 2007. Predicting temperate conifer forest successional stage distributions with multitemporal Landsat Thematic Mapper imagery. Remote Sens. Environ. 106: 2008-237.

Stoker, J., D. Harding, and J. Parrish. 2008. The need for a national lidar dataset. Photogramm. Eng. Remote Sens. 74: 1066-1068.

StromberG, J. C.. 1993. Riparian mesquite forests: A review of their ecology, threats, and recovery potential. J. Ariz.-Nev. Acad. Sci. 27: 111-124.

Turner, W., S. Spector, N. Gardiner, M. Fladeland, E. Sterling, and M. STEININGer. 2003. Remote sensing for biodiversity science and conservation. Trends Ecol. Evolut. 18: 306-314.

Vierling, K. T., C. Bässler, R. Brandl, L. A. Vierling, I. Weiß, and J. MülLER. 2011a. Spinning a laser web: Predicting spider distributions using lidar. Ecol. Appl. 21: 577-588.

Vierling, L. A., S. Martinuzzi, G. P. Asner, J. Stoker, and B. R. Johnson. 2011b. Lidar: Providing structure. Front. Ecol. Environ. 9: 261-262.

Vierling, K. T., L. A. Vierling, W. A. Gould, S. Martinuzzi, and R. ClawGES. 2008. Lidar: Shedding new light on habitat characterization and modeling. Front. Ecol. Environ. 6: 90-98.

Vogeler, J. C., K. T. Vierling, A. T. Hudak, and L. A. Vierling. In review. LiDAR-derived canopy architecture predicts Brown Creeper occupancy of two western coniferous forests. The Condor.

Weber, T. C., AND D. E. Boss. 2009. Use of LiDAR and supplemental data to estimate forest maturity in Charles County, MD, USA. Forest Ecol. Manag. 258: 2068-2075. 